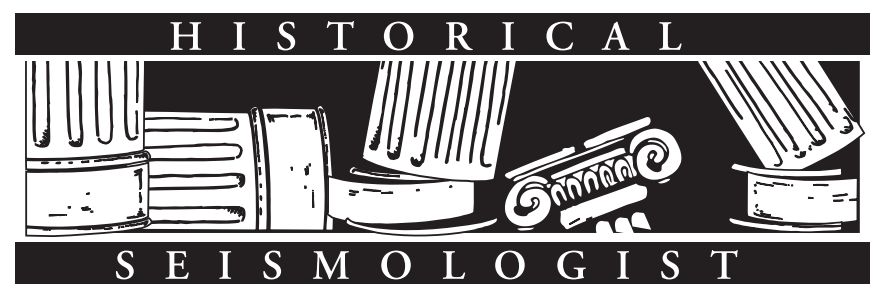

\section{The Origins of an Old Myth: Sir Arthur Evans, Claude Schaeffer and the Seismic Destruction of Late Bronze Age Eastern Mediterranean Civilizations}

\section{by Simon Jusseret and Manuel Sintubin}

\section{INTRODUCTION}

In the history of earthquake archeology in the Mediterranean region, the names of Sir Arthur Evans (1851-1941) and Claude Schaeffer (1898-1982) have become intimately related to the formative stages of the discipline through their association with pioneering theories (cf. Evans, 1928; Schaeffer, 1948) regarding the effects of earthquakes on ancient societies (e.g., Stiros, 1996; Jones and Stiros, 2000; Buck, 2006; Sintubin, 2011). Although strong parallels exist between Evans' (1928) archeological interpretations at Knossos (Crete, Greece; see Fig. 1 for location of archeological sites mentioned in the text) and Schaeffer's (1948) fundamental principles, no evidence exists to date to support direct influence; nowhere in his work does Schaeffer (1948) refer to Evans' (1928), Palace of Minos apart from discussing the chronological implications of "Minoan" (Cretan Bronze Age) material recovered from Near Eastern archeological contexts. Particularly, the source of Schaeffer's (1948) fundamental premises for earthquake catastrophes remains unclear. These premises are:

- the effects of catastrophic earthquakes are widespread;

- catastrophic earthquakes are simultaneously recorded in archeological sites as destruction layers, becoming stratigraphic markers;

- catastrophic earthquakes have the potential of causing political unrest and population movements (see also Hanfmann, 1951).

Unpublished documents from the personal archives and library of Claude Schaeffer, held by the Cyprus American Archaeological Research Institute (CAARI) in Nicosia, may shed some light on the intellectual relationship between Evans and Schaeffer and help us clarify the origin of Schaeffer's (1948) core hypotheses. This issue bears relevance beyond the field of archeoseismology, since Schaeffer's $(1948,1968)$ theory as expanded by Nur and Cline (2000) and Nur and Burgess (2008), is listed in earthquake catalogs as forming the basis of regional seismic hazard assessments (Fraser et al., 2010; Ferry et al., 2011). Moreover, placing Schaeffer's ideas in their appropriate historical context may help substantiate recent claims that the purported collapse of Bronze Age Eastern Mediterranean societies due to seismic events should serve as a source of evidence for quantifying the risk posed by extreme geophysical events to modern civilization (McGuire, 2006).

\section{ARTHUR EVANS AND KNOSSOS}

Arthur Evans (Fig. 2), best known for his excavations at the Neolithic and Bronze Age site of Knossos, first suggested that seismic events punctuated the development of Minoan civilization through catastrophic destructions represented in the archeological record by building damage and stratified deposits of debris. Based on his own archeological observations, and undoubtedly encouraged by his personal experience of a severe earthquake on 26 June 1926 (Evans, 1928; Papadopoulos, 2011), Evans developed a seismic stratigraphical framework in which every major destruction at Knossos was related to seismic action of varying intensity. According to Evans (1928, p. 321), there was little doubt that "these great natural convulsions had political consequences, and that they may have been productive of the uprising of depressed elements in the population, or a change of dynasty." Desertion and emigration were also regarded by Evans (1928, p. 321) as possible cultural correlates of repeated earthquakes.

\section{CLAUDE SCHAEFFER AND THE STRATIGRAPHIE COMPARÉ}

These views, as many pointed out (Drews, 1993; Buck, 2006; Robinson, 2008), share great similarity with those developed about 20 years later by French archeologist Claude Schaeffer (Fig. 3) who also considered earthquakes as both an interpretive tool and a catalyst for cultural change. Excavator of the Bronze Age sites of Ras-Shamra/Ugarit (Syria) and Enkomi (Cyprus), Claude Schaeffer is perhaps best remembered among earthquake archeologists for his Stratigraphie Comparée (1948), a massive volume exposing the conceptual basis of a new archeological methodology defined by him as stratigraphie sismologique. According to this method, archeological destruction layers of supposed seismic origin are used as stratigraphic benchmarks for the chronological correlation of archeological sites throughout the Near East. Schaeffers' Stratigraphie Comparée (1948) also reveals his view on the geological nature of earthquakes, whereby "grandes zones épicentrales" are identified throughout the "Géosynclinal Méditerranéen." When an earthquake occurs, it is considered by Schaeffer to affect the entire 


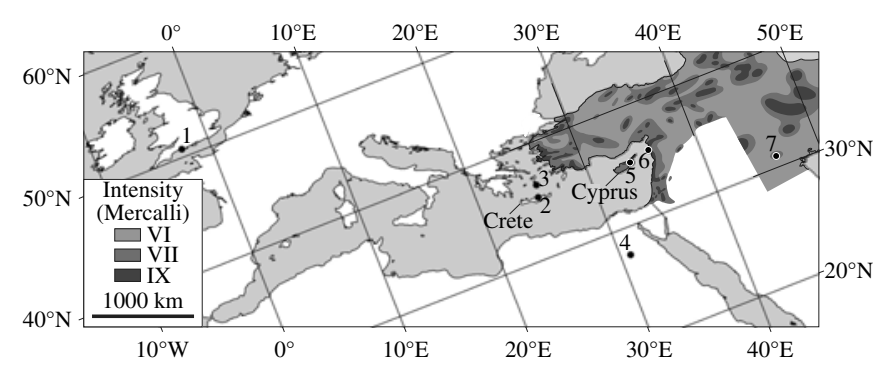

A Figure 1. Location of archeological sites discussed in the text and Near Eastern "grandes zones épicentrales" according to Schaeffer (1948: plate 1). 1. Maiden Castle, 2. Knossos, 3. Akrotiri, 4. Tell el-Amarna, 5. Enkomi, 6. Ugarit, 7. Ur.

"geosyncline" by propagating along faults, as well as along the coasts, and by triggering new earthquakes causing destruction over very long distances throughout the region. Schaeffer furthermore ascribes the higher frequency of major earthquakes during the Bronze Age to the gradual evolution towards an

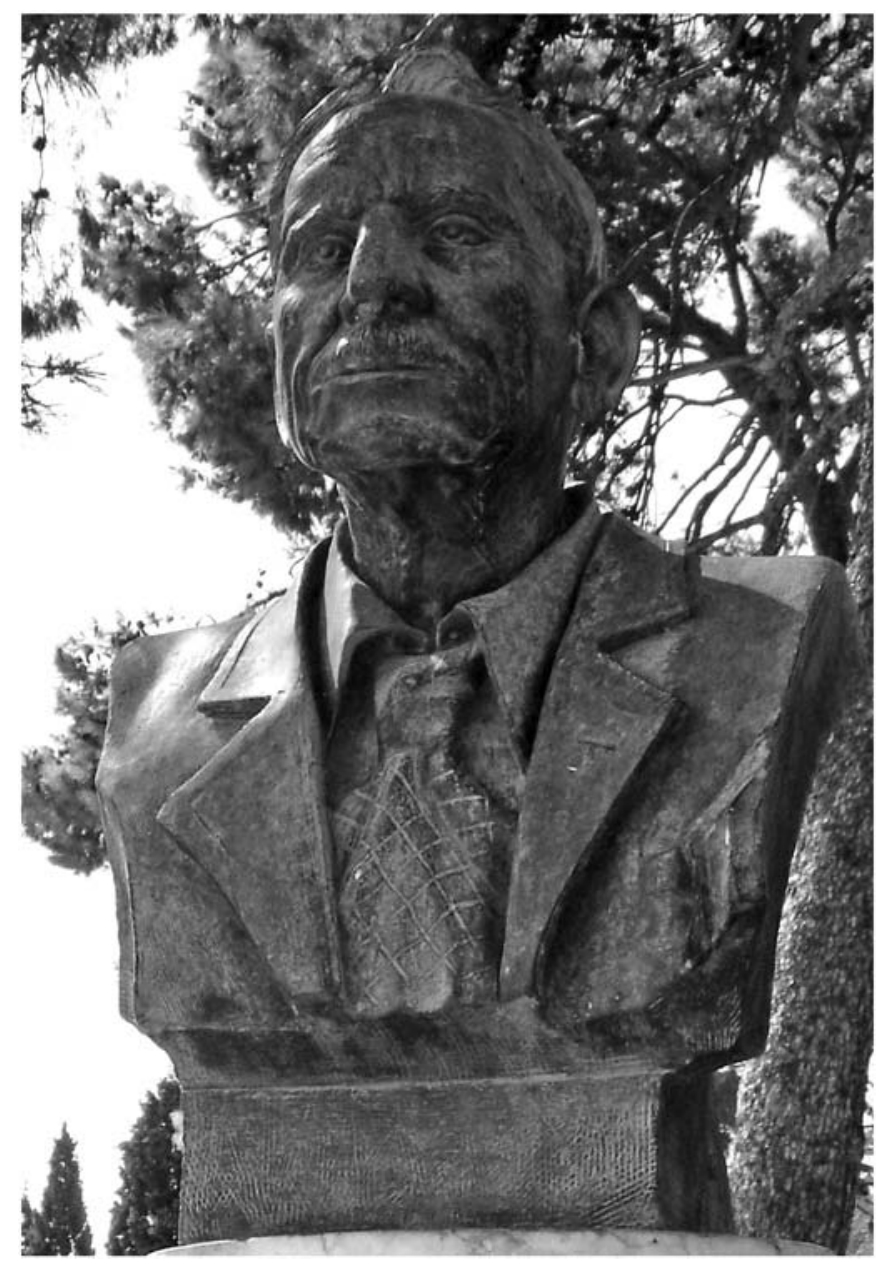

A Figure 2. Bronze statue of Sir Arthur Evans at the site of Knossos, Crete.

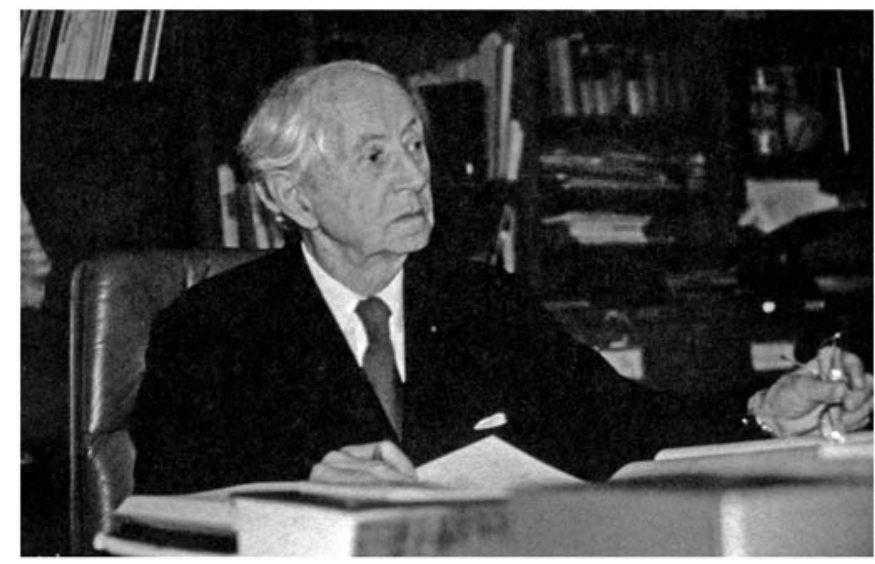

A Figure 3. Claude F. A. Schaeffer (frontispiece of Bergerhof et al., 1979, reproduced with permission).

"équilibre des masses terrestres"-in this case the "Géosynclinal Méditerranéen"-through time, explaining why the Mediterranean region has been spared from earthquake catastrophes in recent times.

The seismic stratigraphy promoted by Schaeffer led him to suggest a seismic origin for several crises which affected the Near East during the third and second millennia. Schaeffer (1948, p. 565-566) argued that catastrophes provoked by destructive earthquakes were potentially responsible for political disruption, site desertions, and population movements, as Evans had argued decades earlier. This hypothesis was carefully advanced in a later publication (Schaeffer, 1968) in the context of the great catastrophe c. 1200 B.C. (Drews, 1993), a widespread event heralding the end of the Bronze Age in the Eastern Mediterranean through waves of destructions and abandonments traditionally related to attacks of the Sea Peoples (e.g. Sherratt, 1998).

Although Schaeffer's hypothesis of widespread seismic destructions c. 1200 B.C. aroused vigorous critique from archeologists (e.g. Drews, 1993) and seismologists alike (e.g. Ambraseys, 1971), it was recently brought back to the fore by the work of Nur and Cline (2000) and Nur and Burgess (2008) who suggested that a series of seismic events or an "earthquake storm" may have struck Near Eastern and Aegean settlements during the period 1225-1175 B.C. According to this view, possible chronological discrepancies between destruction events and widespread distribution of damage-two major points of contention expressed against Schaeffer's (1948) original thesis (Hanfmann, 1951) — can be explained by the progressive liberation of stress along fault segments, giving rise to multidecadal sequences of earthquakes spread over hundreds of kilometers. Although Schaeffer $(1948 ; 1968)$ never suggested the occurrence of a "single huge earthquake" to explain destructions c. 1200 B.C. (contra Nur and Burgess, 2008, p. 238), his interpretations gained scientific credibility (and popular visibility) through Nur and Cline's (2000) and Nur and Burgess' (2008) work. 


\section{THE DOCUMENTS}

The Claude F. A. Schaeffer library at CAARI was officially inaugurated on 9 May 1985 and contains more than 3000 volumes and almost as many offprints originating from Schaeffer's personal library (Albenda, 1986). CAARI's collection also includes the Claude F. A. Schaeffer's Papers, a unique record of Schaeffer's correspondence with renowned mid-twentieth century archeologists, among whom were Arthur Evans, Vere Gordon Childe (one of Europe's most prominent prehistorians from 1925 to 1957), Leonard Woolley (excavator of the royal tombs of Ur, Mesopotamia), Max Mallowan (illustrious Mesopotamian archeologist and husband of Agatha Christie), Mortimer Wheeler (excavator of Maiden Castle, England, and developer of the "Wheeler's box system" of archeological excavation), John Pendlebury (director of excavations at the royal city of Tell el-Amarna, Egypt, from 1930 to 1936 and eminent Minoan archeologist), and Spyridon Marinatos (excavator of Akrotiri, Thera, the "Pompeii of the Aegean").

Schaeffer's interest in Minoan archeology can probably be traced to Evans' research at Knossos early in the twentieth century. Documents from the Claude F. A. Schaeffer Papers suggest personal contacts between the two archeologists. Eighteen letters of Evans were addressed to Schaeffer between 1931 and 1939. These documents mainly concern travel arrangements for Schaeffer's visits to the Ashmolean Museum in Oxford (Evans' professional residence) and inquiries regarding the lending of a Minoan vase fragment on the occasion of the British School at Athens' fiftieth birthday exhibition (OctoberNovember 1936). Although the circumstances of Evans and Schaeffer's first encounter remain unknown, Schaeffer's correspondence contains evidence for a visit of the French archeologist to Knossos in the early 1930s. In a letter dated 26 July 1969 to Greek archeologist Spyridon Marinatos, Schaeffer writes:

"My wife daughter of the S...[?] archaeologist R.

Forrer and I remembering our visit at Knossos at the beginning of the $30^{\text {th }}$ when you were Curator there, look both forward to meet you again after so many years $[\ldots] . "$

This mention would not exclude a visit of Schaeffer to Knossos on the occasion of Evans' last excavation campaign in 1931, leading to the discovery of the so-called Temple Tomb.

Regardless of this uncertainty, two dedicated books from Schaeffer's personal library at CAARI demonstrate the close relationship between Schaeffer and Evans. The first one is authored by Joan Evans, Arthur Evans' half-sister, and represents his first biography, written after his death in 1941 (Evans, 1943). The book was most probably sent to Claude Schaeffer by Joan Evans, who also dedicated the volume to him [en] souvenir de son ami Arthur Evans (Fig. 4).

The second book is the first edition of the first volume of Evans' (1921), Palace of Minos of which the front paste-down has a letter of the book publisher addressed to Claude Schaeffer attached to it:

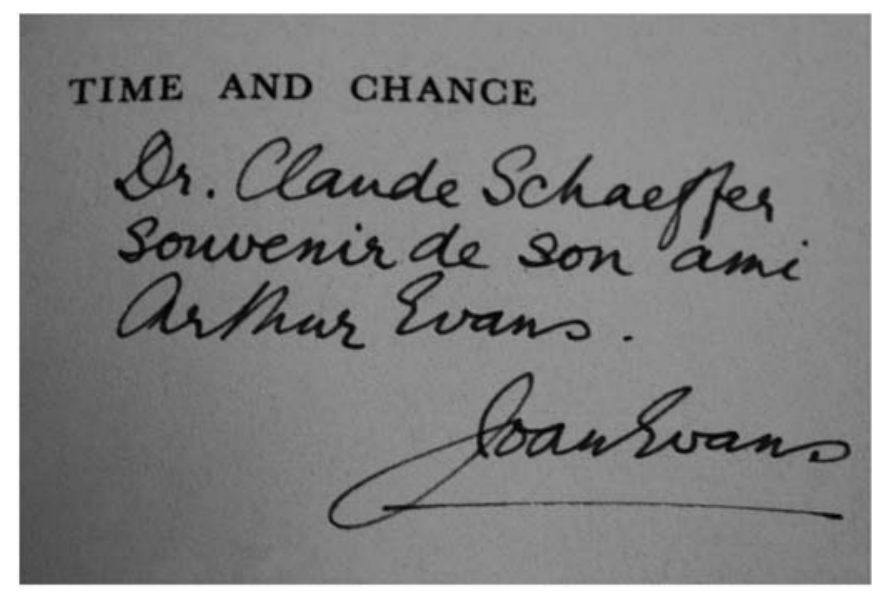

A Figure 4. Dedication of Joan Evans to Claude Schaeffer on Schaeffer's personal copy of Arthur Evans' biography (Evans, 1943).

\section{"Dear Sir,}

We write to advise you that we are sending at the request of the author Sir Arthur Evans a set of his work "The Palace of Minos", four volumes by Parcel Post in two parcels, which we trust will reach you safely."

The backside of the letter bears a note written by Schaeffer and dated 30 June, 1936 (Fig. 5):

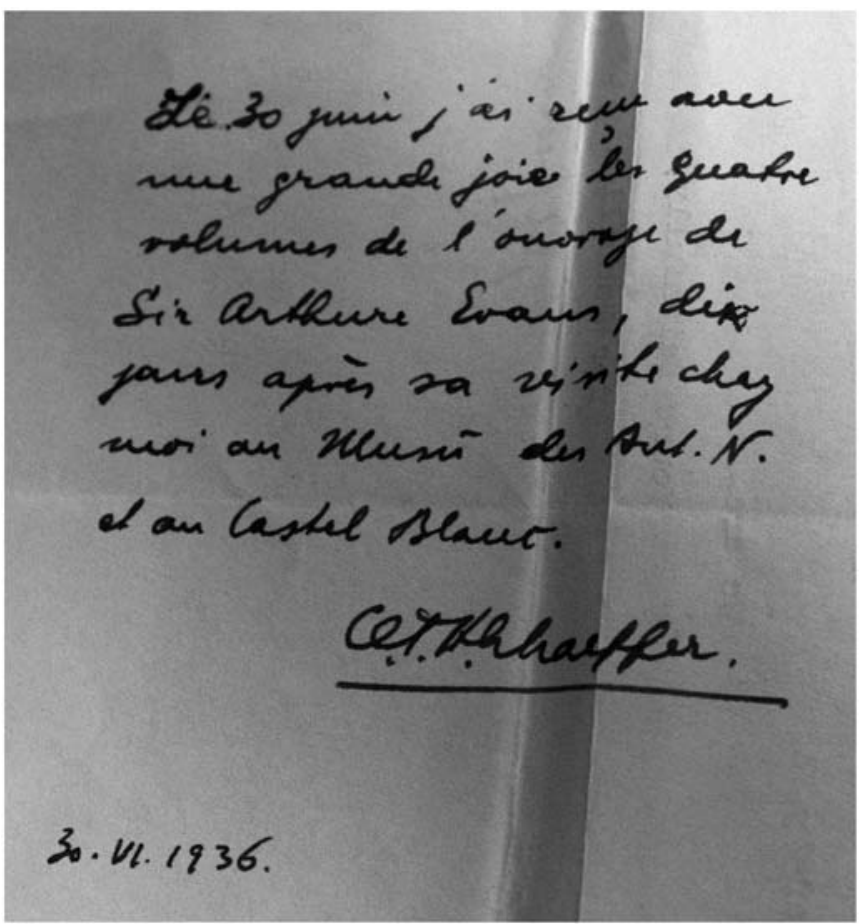

A Figure 5. Schaeffer's note in his copy of the Palace of Minos (Evans, 1921). 
"On June 30 I received to my great delight the four volumes of Sir Arthur Evans' work, ten days after his visit to the Musée des Ant. N. and to the Castel Blanc" (authors' translation)

The front free-end paper of the volume is decorated by a card dedicated by Evans ("With Sir Arthur Evans' compliments") and a photograph of Evans taken by Schaeffer on the occasion of his visit to the Castel Blanc (Schaeffer's residence in Saint-Germain-en-Laye, France) in 1936 (Fig. 6). This information is provided by a note written by Schaeffer on the backside of the photograph:

"Sir arth. Evans

au Castel Blanc

le 20.VI.36."

Although these documents offer firsthand evidence of personal acquaintance between the two archeologists, and may therefore suggest direct exchange of ideas, they do not represent in themselves a satisfactory proof of Evans' intellectual legacy to Schaeffer. More convincing is the evidence provided by Schaeffer's annotations and highlights found in his personal copy of the Palace of Minos (Evans, 1928, 1936). Indeed, these notes allow the recognition of all three of Evans' theoretical premises which underpin the Stratigraphie Comparée (Schaeffer, 1948) and its later development (Schaeffer, 1968).

\section{Premise 1: Seismic Catastrophes have Widespread Effects}

The only hand-written annotation in Schaeffer's personal copy of the Index to the Palace of Minos (Evans, 1936) is situated next to the "earthquakes" entry (Fig. 7a):

"étendue de tr. t. [tremblement de terre] MaltaCandia-Rhodes-Egypte"

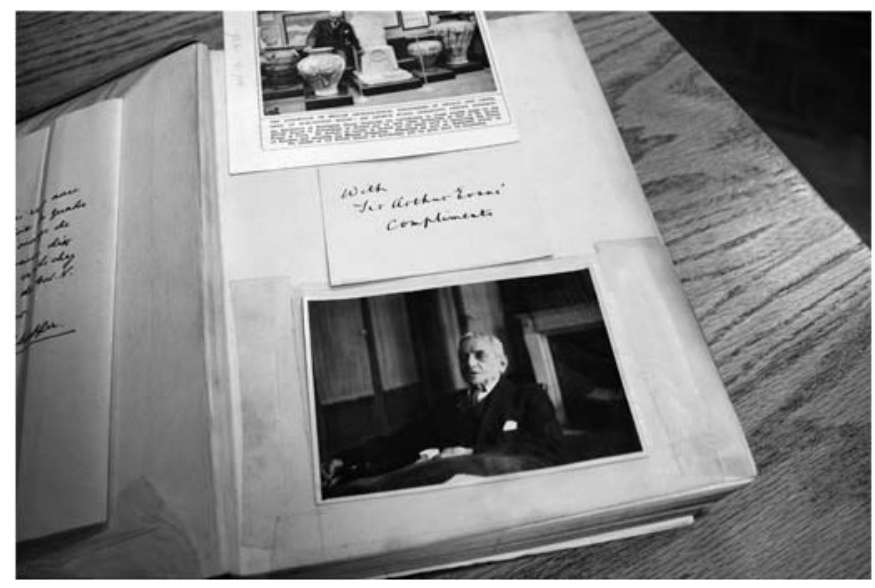

A Figure 6. Photograph of Sir Arthur Evans stuck on the front free-end paper of Schaeffer's personal copy of the Palace of Minos (Evans, 1921).
Moreover, a wavy pencil line highlights the corresponding excerpt (Evans, 1928, p. 315), an account of the effects of the 12 October 1856 earthquake in the Eastern Mediterranean:

"the first of a series of severe shocks was felt at Malta at 2.11 a.m. [October 12, 1856], reaching Candia 19 minutes later. From Eastern Crete the desolating course of the earthquake passed through the intermediate islands of Kasos and Karpathos to Rhodes, the city of which was struck at $2.50 \mathrm{a}$ a.m. with disastrous effects on the castle, towers, mosques, and houses. In the Greek quarter only two out of about a thousand houses remained intact, while many of the inhabitants were buried in the ruins. At the same time a seismic offshoot running South-East affected the NileValley, and some minarets and houses fell at Cairo and Alexandria."

\section{Premise 2: Earthquakes are Recorded as Stratigraphically Significant Destruction Layers}

Red pencil lines accompany Evans' discussion of seismic destructions at Knossos. Particularly, passages highlighted by Schaeffer describe the physical effects of earthquakes (ruin and widespread fire) and their possible role as stratigraphic markers (Fig. 7b):

"it may be observed that at Candia and elsewhere the ruin that an earthquake has wrought has been followed at times by a wide conflagration." (Evans, 1928, p. 320)

\section{Premise 3: Political Unrest and Population Movements are the Consequences of Catastrophic Earthquakes}

Red pencil lines highlight Evans' key ideas regarding the impact of earthquakes on ancient populations:

"political effect" and "emigration" (Evans, 1928, p. 321) (Fig. 7c,d).

Similar marks draw attention to two historical cases provided by Evans:

"This tendency [of earthquakes to provoke desertion and emigration], indeed, is also historically illustrated on the occasion of the great earthquake at Candia of 1508, the first pre-occupation of the Venetian Duke being to prevent the inhabitants from deserting the city. It might even be suggested that the feeling of insecurity thus induced, encouraged the process of overseas conquest which led to the wholesale colonization of Mainland Greece by men of Minoan stock" (Evans, 1928, p. 321).

and

"In the great earthquake that befell Ragusa in 1667, the fall of the upper part of the Palazzo Rettorile overwhelmed not only the Rector of the Republic himself, but about a third of the Senate, then assembling there for a meeting" (Evans, 1928, p. 322). 


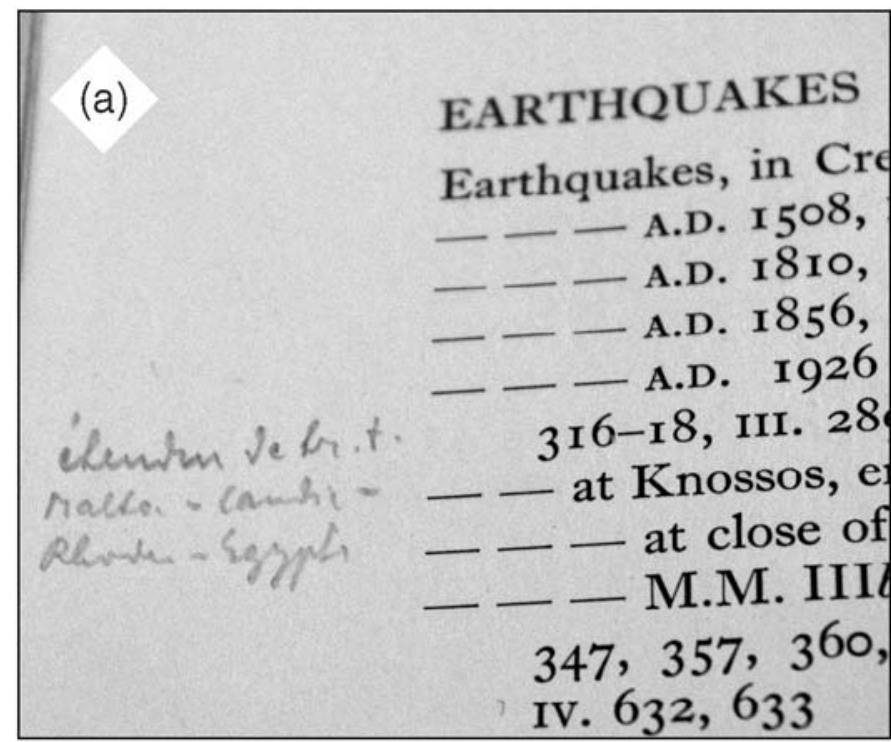

(c)

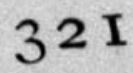

ulsions Political

tive of effect"of
ange of quakes.

1 by the

days of (b) list of early earthquakes at Knossos

ma. oe drawn up.

c. 2100 B.C. (end of M. M. II $a$ : see above, p. 214 seqq.).

c. $175^{\circ}$ B.c. (end of M. M. II $b$ ). Severe.

c. $165^{\circ}$ B.C. (end of M. M. III $a$ ).

c. 1570 B.C. (towards end of M. M. III $b$ ).

c. 1500 B.C. (end of L. M. I $a$ ).

c. 1400 B.C. (end of PalacePeriod-L. M. II).

It must be understood that these dates are approximate and provisional.
$O_{(d)}$ the site

n line cause

and again Impulse throughout emigra ation? This of the great enetian Duke It might even

A Figure 7. (a) Annotation of Schaeffer next to the "earthquakes" entry of the Index to the Palace of Minos (Evans, 1936); (b)(d) Schaeffer's red pencil marks highlighting Evans' (1928) key ideas related to the seismic destructions at Knossos.

\section{CLOSING REMARKS}

From the above documents, it is clear that Schaeffer's (1948) contribution to the field of earthquake archeology can be directly traced to the work of Evans at Knossos. However, where Evans' (1928) views on the impacts of earthquakes on Minoan history remained relatively reserved and hypothetical, a clear interpretive turn occurred with the works of Schaeffer (1948, 1968). Indeed, Schaeffer (1948) bolstered Evans' (1928) ideas by integrating his theory of earthquake catastrophes with contemporary understanding of geological processes, and by suggesting his methodology of inter-site correlation of supposed seismic destruction layers (Buck, 2006). By incorporating the concept of "earthquake storm" in Schaeffer's $(1948,1968)$ thesis, Nur and Cline (2000), and Nur and Burgess
(2008) eventually paved the way for the revival of one of the most enduring myths of Eastern Mediterranean archeology: the collapse of Late Bronze Age societies due to seismic events. However, as Rose (1999) pointed out, use of such interpretive models of societal collapse as a basis for developing contemporary strategies for sustainability is at risk of framing data in an easily digested form reflecting more contemporary concerns with large-scale environmental disasters than archeological evidence (cf. Marriner et al., 2010; Butzer, 2012).

In his recent review of Nur and Burgess' (2008) work, Stiros (2009) raised a critical question: considering the recurrent seismicity of the Eastern Mediterranean, why did earthquakes destroy only the Bronze Age civilizations and not later ones? A possible answer could be sought in the historical (interbellum) context of the idea. As Starr (1984) points out, the 
Bronze Age Minoan civilization is the only great civilization discovered in the twentieth century, and its interpretation by Evans owes much to the general political, social, and emotional climate in early twentieth-century Europe (Bintliff, 1984). Hence, Evans' firm belief that no other civilization gained hegemony over 'his' Minoans and that only natural disasters could cause their collapse can be seen as a retreat into Victorian ideals of peace and prosperity shattered by the carnage of the Great War (cf. Papadopoulos, 2005).

Similarly, could cathartic beliefs lie behind Schaeffer's Bronze Age seismic hypothesis, formulated for the most part in Oxford between 1942 and 1946, and only interrupted when the noise of bombs and anti-aircraft guns was becoming unbearable (Schaeffer, 1948, p. viii)? Schaeffer later wrote to his friend Immanuel Velikovsky (Kogan and Sharon, 1999):

"those great [natural] crises will explain better than before, the historical development of the most ancient civilizations and its mechanism, and they will definitely take out of the hands of man the command of the great historical happenings we thought he possessed." $<$

\section{ACKNOWLEDGMENTS}

S. J. is a postdoctoral researcher of the F. R. S.-FNRS (Belgium). This research has been performed by $S$. J. during his stay at the $\mathrm{KU}$ Leuven as Intercommunity Scientific Postdoctoral Collaborator of the Francqui Foundation. Warm thanks to CAARI director, Andrew McCarthy, for kindly allowing the consultation of unpublished documents from the C. F. A. Schaeffer Papers, to CAARI Board of Trustees, for allowing us to reproduce information from the C. F. A. Schaeffer Papers, to CAARI librarian Evi Karyda, for granting us permission to digitalize excerpts of books from the CAARI library (here reproduced as Figs. 4-7), to Manfried Dietrich and Oswald Loretz, for allowing the reproduction of the photo shown in Fig. 2, to Jan Driessen, for useful comments, and to the Service Image et Publications at Université catholique de Louvain, for assistance with the preparation of the figures. We are grateful for helpful remarks and suggestions provided by an anonymous reviewer. This article is a contribution to the International Geoscience Programme IGCP 567 "Earthquake Archaeology: Archaeoseismology along the Alpine-Himalayan Seismic Zone."

\section{REFERENCES}

Albenda, P. (1986). Milestones 1985-1986, CAARI News 1, 2.

Ambraseys, N. N. (1971). Value of historical records of earthquakes, Nature 232, 375-379.

Bergerhof, K., M. Dietrich, and O. Loretz (Editors) (1979). Internationales Jahrbuch für die Altertumskunde Syrien-Palästinas. Festschrift für Claude F.A. Schaeffer, Ugarit-Forschungen 11, Verlag Butzon \& Bercker and Neukirchener Verlag, Kevelaer and NeukirchenVluyn, $905 \mathrm{pp}$.

Bintliff, J. L. (1984). Structuralism and myth in Minoan studies, Antiquity 58, 33-38.

Buck, V. (2006). Archaeoseismology in the Atalanti Region, Central Mainland Greece: Theories, Methods and Practice, BAR International Series 1552, Archaeopress, Oxford, 110 pp.
Butzer, K. W. (2012). Collapse, environment, and society, Proc. Natl. Acad. Sci. U.S.A. 109, 3632-3639.

Drews, R. (1993). The End of the Bronze Age: Changes in Warfare and the Catastrophe ca. 1200 B.C., Princeton University Press, Princeton, $252 \mathrm{pp}$.

Evans, Sir A. (1921). The Palace of Minos. A Comparative Account of the Successive Stages of the Early Cretan Civilization as Illustrated by the Discoveries at Knossos. Volume I. The Neolithic and Early and Middle Minoan Ages, MacMillan and Co., London, $721 \mathrm{pp}$.

Evans, Sir A. (1928). The Palace of Minos. A Comparative Account of the Successive Stages of the Early Cretan Civilization as Illustrated by the Discoveries at Knossos. Volume II: Part I. Fresh Lights on Origins and External Relations: The Restoration in Town and Palace after Seismic Catastrophe Towards Close of M. M. III, and the Beginnings of the New Era, MacMillan and Co., London, 390 pp.

Evans, J. (1936). Index to the Palace of Minos, MacMillan and Co., London, $221 \mathrm{pp}$.

Evans, J. (1943). Time and Change. The Story of Arthur Evans and his Forebears, Longmans and Green and Co., London, New York, Toronto, $410 \mathrm{pp}$.

Ferry, M., M. Meghraoui, N. Abou Karaki, M. Al-Taj, and L. Khalil (2011). Episodic behavior of the Jordan valley section of the Dead Sea fault inferred from a 14-ka-long integrated catalog of large earthquakes, Bull. Seismol. Soc. Am. 101, 39-67.

Fraser, J., A. Hubert-Ferrari, K. Vanneste, S. Altinok, and L. Drab (2010). A relict paleoseismic record of seven earthquakes between 2000 B.C. and 600 A.D. on the central north Anatolian fault at Elmacik, near Osmancik, Turkey, Bull. Geol. Soc. Am. 122, 1830-1845.

Hanfmann, G. M. A. (1951). The Bronze Age in the Near East: A review article [Part 1], Am. J. Archaeol. 55, 355-365.

Jones, R. E., and S. C. Stiros (2000). The advent of archaeoseismology in the Mediterranean, in The Archaeology of Geological Catastrophes, W. J. McGuire, D. R. Griffiths, P. L. Hancock, and I. S. Stewart (Editors), Geological Society Special Publication, Vol. 171, The Geological Society, London, 25-32.

Kogan, S. V., and R. V. Sharon (1999). Schaeffer to Velikovsky July 23, 1956, VArchive.org. The Immanuel Velikovsky Archive. Available at: http://www.varchive.org/cor/schaeffer/560723sv.htm (last accessed 6 December 2011).

Marriner, N., C. Morhange, and S. Skrimshire (2010). Geoscience meets the four horsemen? Tracking the rise of neocatastrophism, Global Planet. Change 74, 43-48.

McGuire, W. J. (2006). Global risk from extreme geophysical events: Threat identification and assessment, Phil. Trans. Roy. Soc. A 364, 1889-1909.

Nur, A., and D. Burgess (2008). Apocalypse: Earthquakes, Archaeology, and the Wrath of God, Princeton University Press, Princeton, 309 pp.

Nur, A., and E. H. Cline (2000). Poseidon's horses: Plate tectonics and earthquake storms in the Late Bronze Age Aegean and Eastern Mediterranean, J. Archaeol. Sci. 27, 43-63.

Papadopoulos, J. K. (2005). Inventing the Minoans: Archaeology, modernity and the quest for European identity, J. Mediterr. Archaeol. 18, 87-149.

Papadopoulos, G. A. (2011). A Seismic History of Crete: The Hellenic Arc and Trench, Ocelotos, Athens, $415 \mathrm{pp}$.

Robinson, A. (2008). Shaking the foundations of archaeology. Did earthquakes trigger the collapse of ancient civilizations? Nature $\mathbf{4 5 2}$, 689-690.

Rose, M. (1999). Godzilla's attacking Babylon! Archaeology (online features 22 September 1999), http://www.archaeology.org/online/ features/godzilla/index.html (last accessed 8 May 2012).

Schaeffer, C. F. A. (1948). Stratigraphie Comparée et Chronologie de l'Asie Occidentale (IIIe et IIe Millénaires), Oxford University Press, London, $653 \mathrm{pp}$.

Schaeffer, C. F. A. (1968). Commentaires sur les lettres et documents trouvés dans les bibliothèques privées d'Ugarit, in Ugaritica 
$V$. Nouveaux Textes Accadiens, Hourrites et Ugaritiques des Archives et Bibliothèques Privées d'Ugarit. Commentaires des Textes Historiques (Première Partie), J. Nougayrol, E. Laroche, C. Virolleaud, and C. F. A. Schaeffer (Editors), Imprimerie Nationale, Librairie Orientaliste Paul Geuthner, Paris, 607-768.

Sherratt, S. (1998). "Sea Peoples" and the economic structure of the late second millennium in the Eastern Mediterranean, in Mediterranean Peoples in Transition: Thirteenth to Tenth Centuries BCE, S. Gitin, A. Mazar, and E. Stern (Editors), Israel Exploration Society, Jerusalem, 292-313.

Sintubin, M. (2011). Archaeoseismology: Past, present and future, Quaternary Int. 242, 4-10.

Starr, C. G. (1984). Minoan flower lovers, in The Minoan Thalassocracy: Myth and Reality. Proceedings of the Third International Symposium at the Swedish Institute in Athens, 31 May-5 June, 1982, R. Hägg and N. Marinatos (Editors), Swedish Institute at Athens, Stockholm, 9-12.

Stiros, S. C. (1996). Identification of earthquakes from archaeological data: Methodology, criteria and limitations, in Archaeoseismology, S. Stiros and R. E. Jones (Editors), British School at Athens Fitch Laboratory Occasional Paper 7, Institute of Geology and Mineral Exploration, The British School at Athens, Athens, 129-152.

Stiros, S. C. (2009). Nur (A.), Apocalypse. Earthquakes, Archaeology, and the Wrath of God. With Dawn Burgess. Pp. xiv + 309, ills, maps.
Princeton University Press, Princeton and Oxford, 2008. The Classical Review 59, 572-574, doi: http://dx.doi.org/10.1017/ S0009840X09001164.

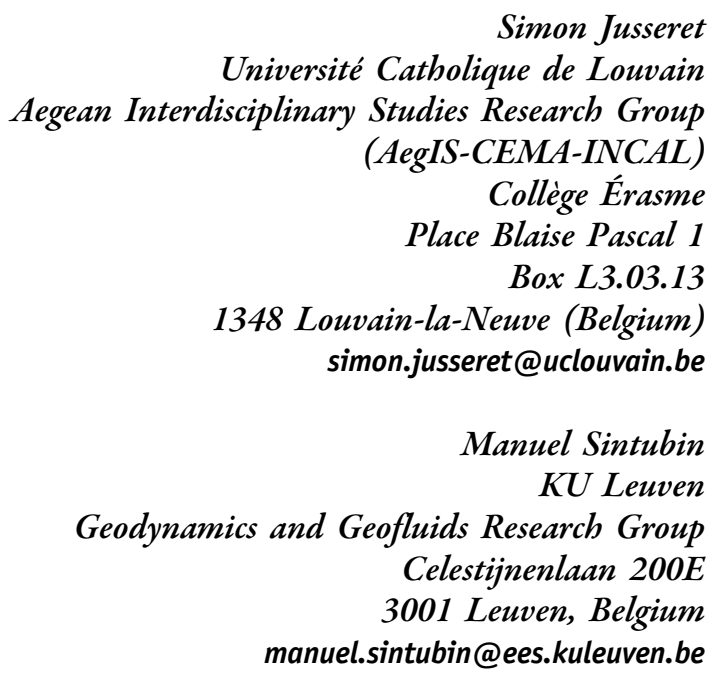

